\title{
Prevalence of dietary supplement use and associated factors among female college students in Saudi Arabia
}

\author{
Hanan Alfawaz ${ }^{1,2}$, Nasiruddin Khan ${ }^{3}$, Aziza Alfaifi', Fatima M. Shahrani ${ }^{1}$, Huda M. Al Tameem', Seetah F. Al Otaibi ${ }^{1}$, \\ Weaam I. Abudigin', Mohammad S. Al-Shayaa ${ }^{4}$, Saad A. Al-Ghanim ${ }^{5}$ and Nasser M. Al-Daghri ${ }^{*}$ (D)
}

\begin{abstract}
Background: The economic boom in Saudi Arabia indirectly prompted the use of dietary supplements in the last two decades. Our aim is to investigate the prevalence of dietary supplement use and its association with sociodemographic/lifestyle characteristics among Saudi female students.

Methods: In this cross-sectional study, 534 female participants ( $\geq 19$ years of age) completed a self-administered questionnaire that include sociodemographic and lifestyle characteristics, perceived health status, dietary supplement use, general awareness, attitudes and behavior.

Results: In all participants, the prevalence of dietary supplement use was $76.6 \%(n=409)$. High level of education $(p=0.002)$ and more physical activity $(p=0.008)$ exhibited a significant positive association with users than to non-users. The frequency showed that beta-carotene (54.2\%), chamomile (54.2\%), and glucosamine (53.8\%) were the most preferred diet supplements under the category "when needed". Cod liver oil (71.3\%), omega 3 (68.3\%), multi-vitamins (61.5\%), ginseng (60\%), and vitamin A (60\%), were mostly used "from time to time". Multi-minerals (34.4\%) were the preferred choice when it comes to daily use. The main reasons for supplement use were to "maintain healthy hair" and "injury and illness" (both 26.2\%). About 38.4\% were not aware and 30.3\% disagree on differences taking supplements with or without consulting a medical professional. About $36.7 \%$ lack information about side effects while, 35.0\% were unaware about any health effect of dietary supplements.
\end{abstract}

Conclusion: The prevalence of dietary supplement use was high in Saudi female students and was significantly associated with sociodemographic and lifestyle factors.

Keywords: Dietary supplements, Sociodemographic, Lifestyle, Saudi Arabia

\section{Background}

The Kingdom of Saudi Arabia is a fast growing economic country that has affected its general population in various ways including a transition in daily lifestyle patterns and dietary intake habits. The pace of change has diverted the traditional Saudi diet towards the so-called Western diets, with increased consumption of energy dense and processed foods leading towards increased prevalence of non-communicable diseases in many Arab regions $[1,2]$.

\footnotetext{
* Correspondence: aldaghri2011@gmail.com

${ }^{2}$ Prince Mutaib Chair for Biomarkers of Osteoporosis, Biochemistry

Department, King Saud University, Riyadh 11451, Saudi Arabia

Full list of author information is available at the end of the article
}

Studies from several regions in Saudi Arabia in different age groups and sex have shown overweight- and obesity-related demographic, socioeconomic status and physical activity factors [3-6]. A recent study performed by our group in Saudi children has shown the influence of knowledge and attitude on vitamin D status [7]. In Saudi Arabia, $66 \%$ of adult men and $71 \%$ of adult women are either overweight or obese [8], indirectly contributing to a very high healthcare burden [9]. Emerging scientific evidence regarding the positive and negative effects of dietary supplements has opened more options to maintain a healthy life [10]. 
Dietary supplements are food products containing dietary ingredients intended to add more nutritional value to a normal diet [11]. There is a lot of evidence on the widespread use of dietary supplements in US and Europe [12-18]. In GCC countries, reports have demonstrated an increase in demand for nutritional supplements [19-22]. For instance, a recent study performed among college students in Qatar revealed a high percentage $(49.6 \%)$ use of nutritional and herbal supplements. In addition, the use of complementary and alternative medicines in the general population and patients with diabetes have been observed in Bahrain and Saudi Arabia, respectively [20, 23]. There are studies regarding the use and awareness of dietary/multi-vitamin and folic acid supplements in pregnant Saudi women [24] as well as vitamin D supplements in Saudi female outpatients [25]. However, only one study exhibited the usage pattern of dietary supplements in professional Saudi male athletes [26]. There is no study present till date providing information about the determinants of dietary supplement use in the female population of Saudi Arabia. To the best of our knowledge, this is the first study of its kind to examine the use of dietary supplements and it association with sociodemographic/lifestyle factors, behavior, and awareness among Saudi female students.

\section{Methods}

\section{Sample size calculation}

Sample size calculation was based on existing literature [27]. With the prevalence of $39 \%$ of dietary supplement use in college students, $5 \%$ margin of error, the required sample size at $95 \%$ confidence interval is 366 patients. After adjusting for non-response of 30\%, 534 female participants were enrolled in the study.

\section{Study population}

The sample population of this cross-sectional study included 319 students randomly selected from science and health colleges (Medicine, Science, Pharmacy, Information Technology, Dentistry and Applied Medical Science) and 215 from Humanitarian colleges (Education, Business Administration, Arts, Tourism/Antique, Law/ Political Science and Language/Translation) of King Saud University, Riyadh, Saudi Arabia. All 534 participants were females aged 19 to 26 years.

\section{Data collection and measurements}

A pilot study (10 students) was performed to confirm the reliability and validity of the questionnaire by using different approaches. We distributed the questionnaire amongst students to get their feedback regarding the understanding and clarity of all questions. The questionnaire was then reviewed by experts in related fields as well as other expert colleagues within the university. We also asked external reviewers to provide their feedback and opinion in developing/improving the questionnaire to ensure reliability of the test and compared the results of our pilot study with the results of similar work done previously. We introduced all necessary expert feedback and suggestions accordingly until we had a final questionnaire which was used in the present study.

The participants were asked to complete the selfadministered questionnaire. It was divided into four parts including sociodemographic/lifestyle characteristic, frequency, type and reason of supplement used in different circumstances and awareness and attitude about use of dietary supplements. Income $<5000$ Saudi Arabia riyals (SAR) was considered low, between 5000 and 9999 SAR was considered average, 10,000-16,000 SAR was considered moderate and $>16,000$ SAR was considered high. The type of physical activity included walking, resistance exercises, swimming and dance. The questionnaire also included sources of spending, motivations, and circumstances for use of dietary supplements. Participants were also asked to respond for the

Table 1 Participants Sociodemographic/lifestyle Characteristics

\begin{tabular}{|c|c|}
\hline Demographics & N (\%) \\
\hline \multicolumn{2}{|l|}{ Age (years) } \\
\hline $19-22$ & $280(52.4)$ \\
\hline $22-24$ & $125(23.4)$ \\
\hline $24-26$ & $52(9.7)$ \\
\hline$>26$ & $77(14.4)$ \\
\hline \multicolumn{2}{|l|}{ BMI Status $\left(\mathrm{kg} / \mathrm{m}^{2}\right)$} \\
\hline Normal & $325(60.9)$ \\
\hline Overweight & $148(27.7)$ \\
\hline Obese & $61(11.4)$ \\
\hline \multicolumn{2}{|l|}{ Social Status } \\
\hline Married & $136(25.5)$ \\
\hline Single & $398(74.5)$ \\
\hline \multicolumn{2}{|l|}{ Monthly Family Income (SAR) } \\
\hline$<5000$ & $57(10.7)$ \\
\hline $5000-10,000$ & $159(29.8)$ \\
\hline $10,000-16,000$ & $148(27.7)$ \\
\hline$>16,000$ & $170(31.8)$ \\
\hline \multicolumn{2}{|l|}{ The Academic Track } \\
\hline Scientific and Medical Colleges & $319(59.7)$ \\
\hline Humanity Colleges & $215(40.3)$ \\
\hline \multicolumn{2}{|l|}{ Educational Level: } \\
\hline 3rd - 5th Level & $236(44.2)$ \\
\hline 6th - 8th Level & $201(37.6)$ \\
\hline > 8th Level & $97(18.2)$ \\
\hline
\end{tabular}

Note: Data presented as frequencies (\%) 
importance of physician's role in diet supplement purchases.

Regarding dietary supplement use, participants were asked whether they were currently taking any supplement together about information on the frequency and duration of use for each dietary supplement reported.

Table 2 Participants History of Disease, Physical activity, Prevalence of Dietary Supplements

\begin{tabular}{|c|c|c|c|}
\hline \multirow[t]{2}{*}{ Parameters } & \multicolumn{2}{|c|}{$\begin{array}{l}\text { Dietary Supplement } \\
\text { Use }\end{array}$} & \multirow[t]{2}{*}{$P$-values } \\
\hline & Yes & No & \\
\hline Age (in Years) & & & 0.234 \\
\hline $19-22$ & $206(73.6)$ & $74(26.4)$ & \\
\hline $22-24$ & $97(77.6)$ & $28(22.4)$ & \\
\hline $24-26$ & $41(78.8)$ & $11(21.2)$ & \\
\hline Higher than 26 & $65(84.4)$ & $12(15.6)$ & \\
\hline Family Income (in Saudi Riyals) & & & 0.135 \\
\hline Less than 5000 & $40(70.2)$ & $17(29.8)$ & \\
\hline $5000-10,000$ & $131(82.4)$ & 28 (17.6) & \\
\hline $10,000-16,000$ & $114(77.0)$ & $34(23.0)$ & \\
\hline Higher than 16,000 & $124(72.9)$ & $46(27.1)$ & \\
\hline Marital Status & & & 0.171 \\
\hline Married & $110(80.9)$ & $26(19.1)$ & \\
\hline Single & $299(75.1)$ & $99(24.9)$ & \\
\hline BMI Status & & & 0.227 \\
\hline Normal & $244(75.1)$ & $81(24.9)$ & \\
\hline Overweight & $113(76.4)$ & $35(23.6)$ & \\
\hline Obese & $52(85.2)$ & $9(14.8)$ & \\
\hline The Academic Track & & & 0.164 \\
\hline Scientific and Medical & $251(78.7)$ & $68(21.3)$ & \\
\hline Humanities & $158(73.5)$ & $57(26.5)$ & \\
\hline Education Level & & & 0.002 \\
\hline 3rd - 5th Level & $167(70.8)$ & $69(29.2)$ & \\
\hline 6th - 8th Level & $156(77.6)$ & $45(22.4)$ & \\
\hline > 8th Level & $86(88.7)$ & $11(11.3)$ & \\
\hline Health Problems & & & 0.095 \\
\hline Vitamin D deficiency & $76(90.5)$ & $8(9.5)$ & \\
\hline Other Disease & $76(81.7)$ & $17(18.3)$ & \\
\hline Physical Activity & & & 0.008 \\
\hline Physical Activity (Yes) & $314(79.5)$ & $81(20.5)$ & \\
\hline Resistance Exercise + Walking (Yes) & $256(79.5)$ & $66(20.5)$ & 0.050 \\
\hline Walk (Yes) & $211(79.0)$ & $56(21.0)$ & 0.184 \\
\hline Resistance Exercise (Yes) & $45(81.8)$ & $10(18.2)$ & 0.334 \\
\hline Swimming (Yes) & $41(78.8)$ & $11(21.2)$ & 0.686 \\
\hline Dance (Yes) & $29(80.6)$ & $7(19.4)$ & 0.561 \\
\hline
\end{tabular}

Note: Data presented as frequencies (\%)

\section{Data analysis}

Cronbach's $\alpha$, an estimate of coefficient of reliability, was measured for the questionnaire and the value obtained was $84 \%$ (excellent). The association between sociodemographic/lifestyle characteristics of respondents and use of supplements were assessed using the Chi-square test or Fisher exact test. Type and use of dietary supplements, reason for use, awareness and attitude, sources of information, spending and purchases were presented as frequency distributions. Analyses were performed using SPSS software, version 16 (SPSS, Chicago, IL, USA). The significance level was set at $P<0.05$.

Table 3 Association between Use of Dietary Supplements, Age, Marital status, Family Income, BMI, Academic Track, Educational Level and Health Problems, physical activity

\begin{tabular}{|c|c|c|c|}
\hline \multirow[t]{2}{*}{ Parameters } & \multicolumn{2}{|c|}{ Dietary Supplement Use } & \multirow[t]{2}{*}{$P$-values } \\
\hline & Yes & No & \\
\hline Age (in Years) & & & 0.234 \\
\hline $19-22$ & $206(73.6)$ & $74(26.4)$ & \\
\hline $22-24$ & $97(77.6)$ & $28(22.4)$ & \\
\hline $24-26$ & $41(78.8)$ & $11(21.2)$ & \\
\hline Higher than 26 & $65(84.4)$ & $12(15.6)$ & \\
\hline Family Income (in Saudi Riyals) & & & 0.135 \\
\hline Less than 5000 & $40(70.2)$ & $17(29.8)$ & \\
\hline $5000-10,000$ & $131(82.4)$ & $28(17.6)$ & \\
\hline $10,000-16,000$ & $114(77.0)$ & $34(23.0)$ & \\
\hline Higher than 16,000 & $124(72.9)$ & $46(27.1)$ & \\
\hline Marital Status & & & 0.171 \\
\hline Married & $110(80.9)$ & $26(19.1)$ & \\
\hline Single & $299(75.1)$ & 99 (24.9) & \\
\hline BMI Status & & & 0.227 \\
\hline Normal & $244(75.1)$ & $81(24.9)$ & \\
\hline Overweight & $113(76.4)$ & 35 (23.6) & \\
\hline Obese & $52(85.2)$ & $9(14.8)$ & \\
\hline The Academic Track & & & 0.164 \\
\hline Scientific and Medical & $251(78.7)$ & $68(21.3)$ & \\
\hline Humanities & $158(73.5)$ & $57(26.5)$ & \\
\hline Education Level & & & 0.002 \\
\hline 3rd - 5th Level & $167(70.8)$ & $69(29.2)$ & \\
\hline 6th - 8th Level & $156(77.6)$ & $45(22.4)$ & \\
\hline > 8th Level & $86(88.7)$ & $11(11.3)$ & \\
\hline Health Problems & & & 0.095 \\
\hline Vitamin D deficiency & $76(90.5)$ & $8(9.5)$ & \\
\hline Other Disease & $76(81.7)$ & $17(18.3)$ & \\
\hline Physical Activity & & & 0.008 \\
\hline Physical Activity (Yes) & $314(79.5)$ & $81(20.5)$ & \\
\hline
\end{tabular}

Note: Data presented as frequencies (\%). $P<0.05$ 
Table 4 Types and Use of Dietary Supplements

\begin{tabular}{|c|c|c|c|c|}
\hline Supplements & As needed & From time to time & Daily & When Sick \\
\hline Active Protein & $9(42.9)$ & $6(28.6)$ & $5(23.8)$ & $1(4.8)$ \\
\hline Beta-carotene & $13(54.2)$ & $7(29.2)$ & $4(16.7)$ & 0 \\
\hline Calcium & $30(28.3)$ & $59(55.7)$ & $8(7.5)$ & $9(8.5)$ \\
\hline Chamomile & $13(54.2)$ & $11(45.8)$ & 0 & 0 \\
\hline Chromium & $7(36.8)$ & $6(31.6)$ & $4(21.1)$ & $2(10.5)$ \\
\hline CO enzyme & $8(47.1)$ & $6(35.3)$ & $2(11.8)$ & $1(5.9)$ \\
\hline Cod liver oil & $15(18.8)$ & $57(71.3)$ & $7(8.8)$ & $1(1.3)$ \\
\hline Folic acid & $30(34.1)$ & $43(48.9)$ & $9(10.2)$ & $6(6.8)$ \\
\hline Garlic capsules & $11(42.3)$ & $14(53.8)$ & 0 & $1(3.8)$ \\
\hline Ginkgo biloba & $7(33.3)$ & $12(57.1)$ & 0 & $2(9.5)$ \\
\hline Ginseng & $6(30.0)$ & $12(60.0)$ & 0 & $2(10.0)$ \\
\hline Glucosamine & $7(53.8)$ & $4(30.8)$ & $1(7.7)$ & $1(7.7)$ \\
\hline Iron & $40(27.6)$ & $66(45.5)$ & $16(11.0)$ & $23(15.9)$ \\
\hline Magnesium & $8(33.3)$ & $11(45.8)$ & $3(12.5)$ & $2(8.3)$ \\
\hline Multi minerals & $8(25.0)$ & $13(40.6)$ & $11(34.4)$ & 0 \\
\hline Multivitamins & 19 (19.8) & $59(61.5)$ & $14(14.6)$ & $4(4.2)$ \\
\hline Omega-3 & $14(17.1)$ & $56(68.3)$ & $11(13.4)$ & $1(1.2)$ \\
\hline Potassium & $7(28.0)$ & $11(44.0)$ & $4(16.0)$ & $3(12.0)$ \\
\hline Vitamin A & $18(22.5)$ & $48(60.0)$ & $11(13.8)$ & $3(3.8)$ \\
\hline Vitamin B12 & $20(30.8)$ & $37(56.9)$ & $6(9.2)$ & $2(3.1)$ \\
\hline Vitamin B Group & 22 (30.6) & $42(58.3)$ & $6(8.3)$ & $2(2.8)$ \\
\hline Vitamin C & $16(25.8)$ & $34(54.8)$ & $6(9.7)$ & $6(9.7)$ \\
\hline Vitamin D & $55(27.1)$ & $114(56.2)$ & $13(6.4)$ & $21(10.3)$ \\
\hline Zinc & $12(20.7)$ & $36(62.1)$ & $7(12.1)$ & $3(5.2)$ \\
\hline
\end{tabular}

Note: Data presented as frequencies (\%)

\section{Results}

Sociodemographic and lifestyle characteristics

Table 1 represents the sociodemographic/lifestyle characteristics of the participants $(n=534)$ (age range; 19 21 years), $23.4 \%$ females (age range; $22-24$ years), 9.7\% females (age range; $24-26$ years), and 14.4\% females (age range; $>27$ years). The majority of the respondents showed normal BMI (60.9\%), marital status (single, 74.5\%), higher family income $(16,000$ SAR, 31.8\%), and education level (3rd - 5th level, 44.2\%).

Table 2 shows the prevalence of dietary supplement use, distribution of participant's dietary history and the type of physical activity. The prevalence of dietary supplement use was $76.6 \%(n=409)$ among female students. In the study population $92.7 \%$ were nonsmokers and $74 \%$ responded positive for daily physical activity with walking as most preferred type.

The association between use of dietary supplements and socioeconomic, demographic factors and physical activity are presented in Table 3. A high level of education $(P=0.002)$, and more physical activity $(P=0.008)$ were both significantly associated with use of dietary supplement than non-users.

\section{Types and use of dietary supplement}

Table 4 shows different types of dietary supplements consumed by the participants at different circumstances: vitamins (A, D, and C), beta-carotene, vitamin B group, vitamin B12, multivitamins, minerals, vitamin/ mineral complexes, muti-minerals ginseng, Ginkgo biloba, chamomile, garlic capsules, CO enzyme, active protein, omega-3, cod liver oil, and glucosamine.

409 (76.6\%) students used at least one of the above mentioned dietary supplements in the past 12 months preceding the study. Based on four categories (when it is needed, from time to time, daily, and during disease),

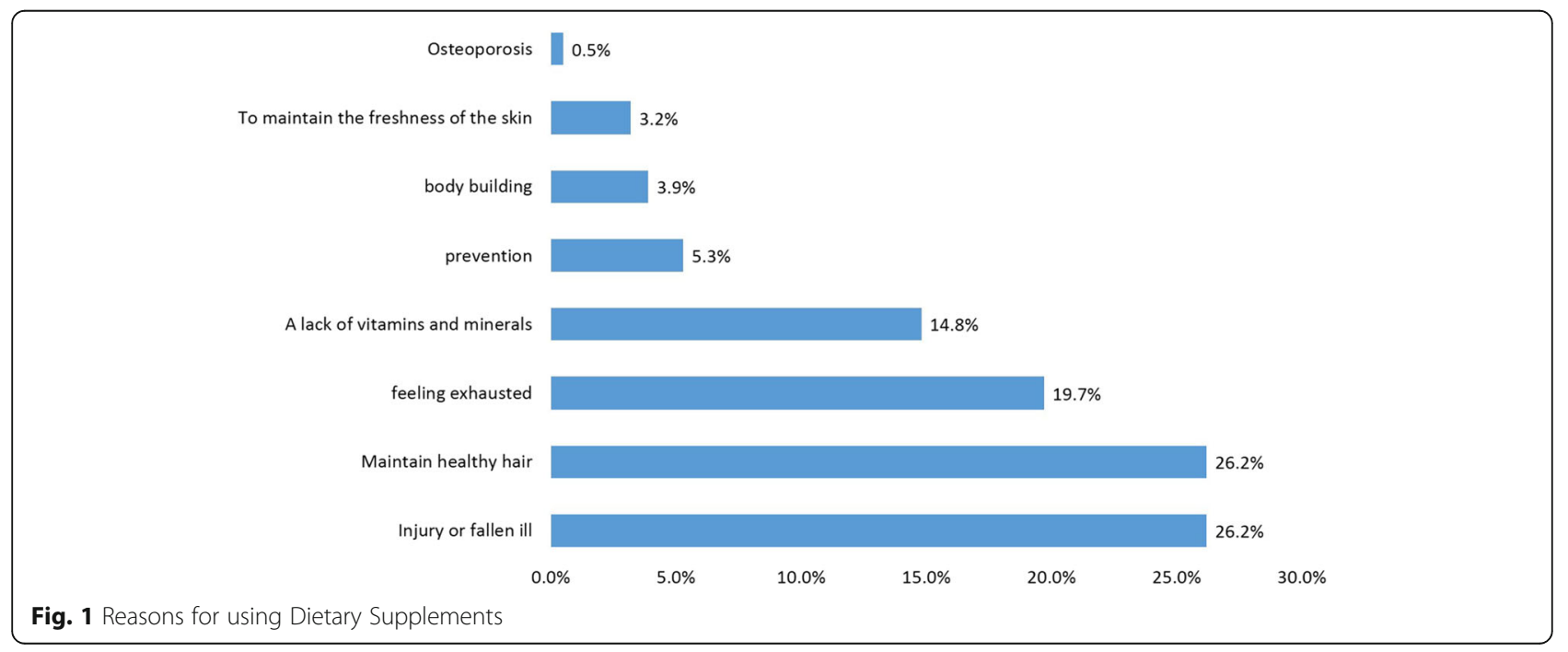


Table 5 Source of Spending, Purchase, Duration of Use and Sources of Information dietary supplementations

\begin{tabular}{|c|c|}
\hline Survey Questions & $N(\%)$ \\
\hline \multicolumn{2}{|c|}{ What is the source of spending on food supplements? } \\
\hline On your account & $339(76.7)$ \\
\hline Free & $61(13.8)$ \\
\hline Insurance & $42(9.5)$ \\
\hline \multicolumn{2}{|c|}{ The purchase of nutritional supplements by? } \\
\hline Prescription & $329(79.3)$ \\
\hline Pharmacies & $63(15.2)$ \\
\hline Internet & $22(5.3)$ \\
\hline The private & $1(0.2)$ \\
\hline \multicolumn{2}{|c|}{ What is the duration of your use of nutritional supplements? } \\
\hline 2 weeks & $104(23.9)$ \\
\hline From time to time & $97(22.2)$ \\
\hline A month & $91(20.9)$ \\
\hline Daily & $62(14.2)$ \\
\hline Weekly & $29(6.7)$ \\
\hline 3 Months & $25(5.7)$ \\
\hline 6 Months & $15(3.4)$ \\
\hline One year & $13(3.0)$ \\
\hline \multicolumn{2}{|c|}{ Information Sources on Supplements } \\
\hline Social Media & $203(38.0)$ \\
\hline Internet & 85 (15.9) \\
\hline Newspapers & $58(10.9)$ \\
\hline Family & $44(8.2)$ \\
\hline More than one source & $40(7.5)$ \\
\hline Physician & $39(7.3)$ \\
\hline Pharmacies & $28(5.2)$ \\
\hline Friends & $26(4.9)$ \\
\hline The books & $11(2.1)$ \\
\hline
\end{tabular}

Note: Data presented as frequencies (\%) the frequency for dietary supplements use showed that beta-carotene $(54.2 \%)$, chamomile $(54.2 \%)$, and glucosamine $(53.8 \%)$ were the most preferred diet supplements in the category "when needed". Cod liver oil (71.3\%), omega 3 (68.3\%), multi-vitamins (61.5\%), ginseng (60\%), and vitamin A (60\%), were among the most frequently used supplement under the category (from time to time). Multi-minerals (34.4\%) was the preferred choice for daily use. Iron (15.9\%) and potassium (12\%) supplements were common in the diseased category (Table 4).

\section{Reasons for the use of dietary supplements}

Reasons for the use of dietary supplements was presented in Fig. 1. These include to "maintain healthy hair" and in "injury and illness" (both at 26.2\%).

\section{Sources of spending, purchase information, and duration of use of dietary supplementations}

The sources of spending, motivation, circumstances, duration of use and sources of information about dietary supplementation are presented in Table 5. Dietary supplements were mainly purchased at their own expense (76.7\%) following only a medical prescription $(79.3 \%)$ for a maximum of two weeks (23.9\%). Social media was the most common source (38\%) of information for dietary supplements.

\section{Awareness and attitude about supplements use}

Table 6 lists the questions about the general awareness and attitudes in the use of dietary supplements. Majority of the participants $(70.6 \%)$ use dietary supplements following a doctor's prescription but $38.4 \%$ do not know the difference between taking the supplements with or without consulting a medical professional while $30.3 \%$ claim there is no difference. Majority of them (40.1\%) read the attached guide/medical instructions before use of dietary supplements. About $36.9 \%$ agreed that there are negative side effects of dietary supplements with $36.7 \%$ of students unaware of this fact. Almost $40 \%$ of the participants responded positively to the

Table 6 Awareness and Attitudes about Supplement Use

\begin{tabular}{|c|c|c|c|c|}
\hline $\begin{array}{l}\text { Awareness and Attitudes } \\
\text { Do you... }\end{array}$ & Yes & No & Sometimes & I don't know \\
\hline Take dietary supplements based on a prescription through a doctor? & $377(70.6)$ & $55(10.3)$ & $56(10.5)$ & $46(8.6)$ \\
\hline $\begin{array}{l}\text { Think that there is a difference between taking the supplements with or } \\
\text { without by medical consult? }\end{array}$ & $115(21.5)$ & $162(30.3)$ & $52(9.7)$ & $205(38.4)$ \\
\hline Read the attached instructions with the supplement? & $214(40.1)$ & $142(26.6)$ & $61(11.4)$ & $117(21.9)$ \\
\hline Think that dietary supplements have any negative side effects? & $197(36.9)$ & $74(13.9)$ & $67(12.5)$ & $196(36.7)$ \\
\hline See the food supplements essential for your health? & $212(39.7)$ & $38(7.1)$ & $97(18.2)$ & $187(35.0)$ \\
\hline Think that dietary supplements substitute for food diversity & $65(12.2)$ & $205(38.4)$ & $54(10.1)$ & $210(39.3)$ \\
\hline Know that you have to do lab test to check levels of vitamins and minerals? & 194 (36.3) & $252(47.2)$ & $88(16.5)$ & - \\
\hline
\end{tabular}

Note: Data presented as frequencies (\%) 
consideration of food supplements being essential for their health. However, 35\% were unaware of this information.

\section{Discussion}

The present study demonstrated the high prevalence of dietary supplement use and its association with sociodemographic and lifestyle factors in female student at King Saud University, Saudi Arabia. The association between higher education level and dietary supplement use has been shown in various studies. Pouchieu and colleagues demonstrated a significant direct association of higher level of education and dietary supplement use in French adult population [28]. Similarly, a study performed by Mileva-Peceva et al. reported a significantly higher consumption of vitamins and/or mineral food supplements in females with a higher educational status [18]. Our present study supports the above findings showing a significant direct association between level of education and dietary supplements use.

Studies across different populations and sex show a healthier lifestyle associated with dietary supplement use [29-31]. A study performed by Kim et al. [32] in a Korean population (men and women) showed that dietary supplement users were more likely to be engaged in moderate or vigorous physical activity. Pouchieu and colleagues [28] also reported that women with higher use of dietary supplements showed high level of physical activity. Our present study supported the above results showing a significant direct association of physical activity with dietary supplement users. Although awareness of dietary supplements use based on a prescription by a physician was high $(70.6 \%$, and $79.3 \%$, respectively), participants lack proper information and basic knowledge about side effects, importance of doctor's prescription and reliable source. A possible cause for this unawareness could be the lack of proper counseling and recommendations about healthy diet from time to time via reliable sources like physicians and experts. The present study has some limitations and should be considered before extrapolating the results to the general public. The present findings cannot be generalized due to small sample size, which is not representative of the overall female population in Saudi Arabia. Due to the cross-sectional design of this study, the reported associations, particularly with respect to sociodemographic/lifestyle characteristic and health outcomes could not establish causality.

\section{Conclusions}

In conclusion, the present study provided new information regarding the high prevalence of dietary supplement use among females in Saudi Arabia. The study reported a significant direct association between higher level of education, physical activity and the use of dietary supplements. Moreover, the study emphasizes the need for increased awareness and basic knowledge related to side effects and source of reliable information for the use of dietary supplements. Finally, the present study highlights the need to have expert healthcare practitioners in the related field for proper and timely guidance in general population.

\section{Abbreviations}

BMI: Body mass index; GCC: Gulf Cooperation Council; MOH: Ministry of Health; SAR: Saudi Arabian Riyals; SPSS: Statistical Package for the Social Sciences; UAE: United Arab Emirates

\section{Acknowledgments}

The authors are grateful to Mr. Syed Danish Hussain for the statistical analysis of the data.

\section{Funding}

The project was supported by King Saud University, Deanship of Scientific Research, Prince Mutaib Bin Abdullah Chair for Biomarkers of Osteoporosis The funding body has no role in the design of the study and collection, analysis and interpretation of data and in writing of the manuscript.

\section{Availability of data and materials}

Data available upon request to the joint corresponding authors.

\section{Authors' contributions}

HA, NMA and MSA contributed to the study design. Subject selection and data collection were performed by AA, FMS, HMA, SFA and WIA. Manuscript draft preparation was done by NK and HA. Data interpretation was done by AA, FMS, HMA, SFA, WIA and MSA. Manuscript was reviewed by MSA, SAA and NMA. All authors (HA, NK, AA, FMS, HMA, SFA, WIA, MSA, SAA and NMA) have read and approved the final manuscript.

Ethics approval and consent to participate

The volunteers provided written informed consent for study participation that was conducted between March-May 2016. Ethical approval for the study protocol was obtained from the institutional review boards of the College of Applied Medical Sciences, King Saud University.

\section{Consent for publication}

Not applicable.

\section{Competing interests}

The authors declare that they have no competing interests.

\section{Publisher's Note}

Springer Nature remains neutral with regard to jurisdictional claims in published maps and institutional affiliations.

\section{Author details}

${ }^{1}$ College of Food Science \& Agriculture, Department of Food Science \& Nutrition, King Saud University, Riyadh, Saudi Arabia. ${ }^{2}$ Prince Mutaib Chair for Biomarkers of Osteoporosis, Biochemistry Department, King Saud University, Riyadh 11451, Saudi Arabia. ${ }^{3}$ College of Applied Sciences, Department of Food Science and Human Nutrition, A'Sharqiyah University, Ibra 400, Sultanate of Oman. ${ }^{4}$ Department of Agricultural Extension and Rural Sociology, College of Foods and Agricultural Sciences, King Saud University, Riyadh, Saudi Arabia. ${ }^{5}$ Health and Hospital Administration Program,

Department of Health Administration, College of Business Administration, King Saud University, Riyadh, Saudi Arabia.

Received: 22 December 2016 Accepted: 15 November 2017 Published online: 22 November 2017

\section{References}

1. Al-Hazzaa HM. Physical activity, fitness and fatness among Saudi children and adolescents: implications for cardiovascular health. Saudi Med J. 2002;23:144-50 
2. Musaiger AO. Overweight and obesity in the eastern Mediterranean region: can we control it? East Mediterr Health J. 2004;10:789-93.

3. Washi SA, Ageib MB. Poor diet quality and food habits are related to impaired nutritional status in 13- to 18-year-old adolescents in Jeddah. Nutr Res. 2010;30:527-34.

4. Al-Daghri NM, Al-Attas OS, Alokail MS, Alkharfy KM, Yakout SM, Sabico SB, Gibson GC, Chrousos GP, Kumar S. Parent-offspring transmission of adipocytokine levels and their associations with metabolic traits. PLoS One. 2011;6(4):e18182.

5. Al-Nuaim AA, Al-Nakeeb Y, Lyons M, Al-Hazzaa HM, Nevill A, Collins P, Duncan MJ. The prevalence of physical activity and sedentary behaviours relative to obesity among adolescents from Al-Ahsa, Saudi Arabia: rural versus urban variations. J Nutr Metab. 2012;2012:417589.

6. Al-Daghri NM, Al-Othman A, Alkharfy KM, Alokail MS, Khan N, Alfawaz HA, Aiswaidan IA, Chrousos GP. Assessment of selected nutrients intake and adipocytokines profile among Saudi children and adults. Endocr J. 2012;59(12):1057-63.

7. Al-Daghri NM, Alkharfy KM, Al-Attas OS, Khan N, Alfawaz HA, Alghanim SA, Al-Yousef MA, Al-Ajlan AS, Alokail MS. Gender-dependent associations between socioeconomic status and metabolic syndrome: a cross-sectional study in the adult Saudi population. BMC Cardiovasc Disord. 2014;14:51.

8. Ng SW, Zaghloul S, Ali HI, Harrison G, Popkin BM. The prevalence and trends of overweight, obesity and nutrition-related non-communicable diseases in the Arabian gulf states. Obes Rev. 2011;12:1-13.

9. Diabetes Atlas, International diabetes federation, 2010. http://www.diabetesatlas. com/content/middle-east-and-northafrica (Last accessed on 08 October 2016).

10. Ernst E, Pittler MH, Wider B. The desktop guide to complementary and alternative medicine. 2nd ed. London: Mosby Elsevier; 2006.

11. DSHEA, Dietary Supplement Health and Education Act of 1994. Pub L No103-417, 108 Stat 4325, 994

12. Bailey RL, Gahche JJ, Lentino CV, Dwyer JT, Engel JS, Thomas PR, Betz JM, Sempos CT, Picciano MF. Dietary supplement use in the United States, 2003-2006. J Nutr. 2011:141:261-6.

13. Gahche J, Bailey R, Burt V, Hughes J, Yetley E, Dwyer J, Picciano MF, McDowell M, Sempos C. Dietary supplement use among U.S. adults has increased since NHANES III (1988-1994). NCHS Data Brief. 2011;61:1-8.

14. Gardiner P, Kemper KJ, Legedza A, Phillips RS. Factors associated with herb and dietary supplement use by young adults in the United States. BMC Complement Altern Med. 2007;7:39.

15. Murphy SP, Wilkens LR, Monroe KR, Steffen AD, Yonemori KM, Morimoto $Y$, Albright CL. Dietary supplement use within a multiethnic population as measured by a unique inventory method. J Am Diet Assoc. 2011;111(7):1065-72.

16. Skeie $G$, Braaten $T$, Hjartåker $A$, Lentjes M, Amiano P, Jakszyn P, Pala V, Palanca A, Niekerk EM, Verhagen H, Avloniti K, Psaltopoulou T, Niravong M, Touvier M, Nimptsch K, Haubrock J, Walker L, Spencer EA, Roswall N, Olsen A, Wallström P, Nilsson S, Casagrande C, Deharveng G, Hellström V, BoutronRuault MC, Tiønneland A, Joensen AM, Clavel-Chapelon F, Trichopoulou A, Martinez C, Rodríguez L, Frasca G, Sacerdote C, Peeters PH, Linseisen J, Schienkiewitz A, Welch AA, Manjer J, Ferrari P, Riboli E, Bingham S, Engeset $D$, Lund $E$, Slimani N. Use of dietary supplements in the European prospective investigation into cancer and nutrition calibration study. Eur J Clin Nutr. 2009:63(Suppl 4):S226-38.

17. Marques-Vidal PI, Pécoud A, Hayoz D, Paccaud F, Mooser V, Waeber G, Vollenweider P. Prevalence and characteristics of vitamin or dietary supplement users in Lausanne, Switzerland: the CoLaus study. Eur J Clin Nutr. 2009:63:273-8.

18. Mileva-Peceva Rl, Zafirova-Ivanovska B, Milev M, Bogdanovska A, Pawlak R. Sociodemographic predictors and reasons for vitamin and/or mineral food supplement use in a group of outpatients in Skopje. Prilozi. 2011;32(1):127-39.

19. GCC pharmaceutical industry report 2013. Dubai, United Arab Emirates: Alpen Capital; 2013 (http://www.alpencapital.\%20com/media-reports-2013. htm, Last accessed 18 July 2014).

20. Al-Faris EA, Al-Rowais N, Mohamed AG, Al-Rukban MO, Al- Kurdi A. Balla alNoor MA, al-Harby S, sheikh a. Prevalence and pattern of alternative medicine use: the results of a household survey. Ann Saudi Med. 2008;28(1):4-10.

21. AI Shaar IA, Ismail MF, Yousuf WA, Salama RE. Knowledge, attitudes and practice of general practitioners towards complementary and alternative medicine in Doha. Qatar East Mediterr Health J. 2010;16(5):522-7.

22. Mathew El, Muttappallymyalil J, Sreedharan J, Lj J, John J, Mehboob M, Mathew A. Self-reported use of complementary and alternative medicine among the health care consumers at a tertiary care center in Ajman, United Arab Emirates. Ann Med Health Sci Res. 2013;3(2):215-9.
23. Khalaf AJ, Whitford DL. The use of complementary and alternative medicine by patients with diabetes mellitus in Bahrain: a cross-sectional study. BMC Complement Altern Med. 2010;14;10:35.

24. Nora A. Al-Faris. High Prevalence of Vitamin D Deficiency among Pregnant Saudi Women. Nutrients. 2016;4;8(2):77.

25. Kanan RMl, Al Saleh YM, Fakhoury HM, Adham M, Aljaser S, Tamimi W. Yearround vitamin D deficiency among Saudi female out-patients. Public Health Nutr. 2013;16(3):544-8.

26. Sulaiman O. Aljaloud and Salam a. Ibrahim. Use of dietary supplements among professional athletes in Saudi Arabia. J Nutr Metab. 2013;2013:245349.

27. Alhomoud FK, Basil M, Bondarev A. Knowledge, attitudes and practices (KAP) relating to dietary supplements among health sciences and nonhealth sciences students in one of the universities of United Arab Emirates (UAE). J Clin Diagn Res. 2016 Sep;10(9):JC05-9.

28. Pouchieu Cl, Andreeva VA, Péneau S, Kesse-Guyot E, Lassale C, Hercberg S, Touvier M. Sociodemographic, lifestyle and dietary correlates of dietary supplement use in a large sample of French adults: results from the NutriNet-Santé cohort study. Br J Nutr. 2013;110(8):1480-91.

29. Marques-Vidal P, Arveiler D, Evans A, Montaye M, Ruidavets JB, Haas B, et al. Characteristics of male vitamin supplement users aged $50-59$ years in France and Northern Ireland: the PRIME study. Prospective epidemiological study of myocardial infarction. Int J Vitam Nutr Res. 2000;70(3):102-9.

30. Block G, Jensen CD, Norkus EP, Dalvi TB, Wong LG, McManus JF, et al. Usage patterns, health, and nutritional status of long-term multiple dietary supplement users: a cross sectional study. Nutr J. 2007;6:30.

31. Radimer KL, Subar AF, Thompson FE. Nonvitamin, nonmineral dietary supplements: issues and findings from NHANES III. J Am Diet Assoc. 2000;100(4):447-54

32. Kim Jl, Lee JS, Shin A, Kang MH, Shin DS, Chung HR, Kim WK. Sociodemographic and lifestyle factors are associated with the use of dietary supplements in a Korean population. J Epidemiol. 2010;20(3):197-203.

\section{Submit your next manuscript to BioMed Central and we will help you at every step:}

- We accept pre-submission inquiries

- Our selector tool helps you to find the most relevant journal

- We provide round the clock customer support

- Convenient online submission

- Thorough peer review

- Inclusion in PubMed and all major indexing services

- Maximum visibility for your research

Submit your manuscript at www.biomedcentral.com/submit
) Biomed Central 